IZA DP No. 10399

Who Is Your Perfect Match? Educational Norms, Educational Mismatch and Firm Profitability

Stephan Kampelmann

Benoît Mahy

François Rycx

Guillaume Vermeylen

November 2016 


\title{
Who Is Your Perfect Match? Educational Norms, Educational Mismatch and Firm Profitability
}

\author{
Stephan Kampelmann \\ Université libre de Bruxelles, SBS-EM (CEB, DULBEA)
}

Benoît Mahy

Université de Mons, humanOrg

François Rycx

Université libre de Bruxelles, SBS-EM (CEB, DULBEA),

Université catholique de Louvain (IRES), Université de Mons, humanOrg and IZA

Guillaume Vermeylen

Université de Mons, humanOrg, IWEPS and Université libre de Bruxelles, SBS-EM (CEB)

\section{Discussion Paper No. 10399 \\ November 2016}

\author{
IZA \\ P.O. Box 7240 \\ 53072 Bonn \\ Germany \\ Phone: $+49-228-3894-0$ \\ Fax: +49-228-3894-180 \\ E-mail: iza@iza.org
}

Any opinions expressed here are those of the author(s) and not those of IZA. Research published in this series may include views on policy, but the institute itself takes no institutional policy positions. The IZA research network is committed to the IZA Guiding Principles of Research Integrity.

The Institute for the Study of Labor (IZA) in Bonn is a local and virtual international research center and a place of communication between science, politics and business. IZA is an independent nonprofit organization supported by Deutsche Post Foundation. The center is associated with the University of Bonn and offers a stimulating research environment through its international network, workshops and conferences, data service, project support, research visits and doctoral program. IZA engages in (i) original and internationally competitive research in all fields of labor economics, (ii) development of policy concepts, and (iii) dissemination of research results and concepts to the interested public.

IZA Discussion Papers often represent preliminary work and are circulated to encourage discussion. Citation of such a paper should account for its provisional character. A revised version may be available directly from the author. 
IZA Discussion Paper No. 10399

November 2016

\section{ABSTRACT}

\section{Who Is Your Perfect Match? Educational Norms, Educational Mismatch and Firm Profitability}

We provide first evidence regarding the direct effect of educational norms and educational mismatch on the bottom line of firms across work environments. To do so, we use rich Belgian linked employer-employee panel data, rely on the methodological approach pioneered by Hellerstein et al. (1999), and estimate dynamic panel data models at the firm level. Our findings show an 'inverted L' profitability profile: undereducation is associated with lower profits, whereas higher levels of normal and overeducation are correlated with positive economic rents of roughly the same magnitude. The size of these effects is amplified in firms experiencing economic uncertainty or operating in high-tech sectors.

JEL Classification: J21, J24

Keywords: educational mismatch, productivity-wage gaps, linked panel data

Corresponding author:

François Rycx

SBS-EM

Université libre de Bruxelles

CP114/2, Avenue F.D. Roosevelt 50

B-1050, Brussels

Belgium

E-mail: frycx@ulb.ac.be

\footnotetext{
* The authors are most grateful to Statistics Belgium for giving access to the data. Funding for this research was provided by the Walloon Region (IPRA Research Grant, IWEPS).
} 


\section{Introduction}

Rising levels of average education in OECD economies imply that prevailing norms regarding the educational attainment of the workforce also increase. This seems to correspond to a higher demand for skills (McGuinness, 2006; Quintini, 2011), for which educational diplomas are generally considered to be proxies. This paper provides empirical evidence on three unresolved questions that are linked to this development. First, we estimate how upgrading the firm's job mix towards jobs with higher educational norms affects profitability at the firmlevel. Unlike much of the earlier empirical literature on educational norms, our econometric estimates from Belgium are based on direct measures of labour productivity and labour costs. They are also robust to a range of measurement issues such as time-invariant labour heterogeneity and firm characteristics. Second, we provide evidence on what happens when firms hire workers who do not match the respective educational norm in the jobs for which they are employed. Building on the literature on educational mismatch (Baert et al., 2013; Baert and Verhaest, 2014; Freeman, 1964; Hartog, 2000; Mavromaras and McGuinness, 2012; McGuinness and Sloane, 2011; Verhaest and Omey, 2009, 2012; Verhaest and Van der Velden, 2013; Sanchez-Sanchez and McGuinness 2015; Sattinger and Hartog, 2013), in which direct measures of productivity are still rare (Grunau, 2016, Kampelmann and Rycx, 2012; Mahy et al., 2015) and direct measures of gaps between labour productivity and costs (i.e. profits) have so far not been estimated, the paper shows that up- and downward deviations from the educational norm in a job do not have the same consequences: all models suggest that the extent of undereducation is in general harmful for firm profits ${ }^{1}$, whereas higher levels of normal ${ }^{2}$ and overeducation are correlated with positive economic rents of roughly the same magnitude. Third, we show that the level of educational norms - and deviations from prevailing norms - are more consequential in some parts of the economy than in others. In this regard, our results suggest that they exert a minor impact in sectors characterised by low uncertainty but a stronger effect in high-tech industries.

The rapid expansion in educational attainment in OECD countries, along with persistent difficulties to accurately match the education of employees to the levels required to carry out specific jobs, means that all three questions addressed in this paper are highly relevant for

\footnotetext{
${ }^{1}$ Undereducation may notably result from labour shortages (i.e. bottleneck vacancies) or technologicallyinduced changes in job content and complexity.

${ }^{2}$ By 'normal' education, we refer to what is generally called 'required' education in the educational mismatch literature. In this manuscript, we use normal education, educational norm and required education as synonymous.
} 
economic and educational policy as well as for firm behaviour (Mavromaras and McGuinness, 2012; Quintini, 2011; Sattinger and Hartog, 2013). In a strategy from 2009, the European Union wants to increase the proportion of individuals with tertiary education in the age group between $30-34$ years to $40 \%$ by 2020 , a development that requires substantial investments in education systems. In 2000, 22.4\% of the population in EU27 countries was tertiary educated, a proportion that already increased to $34.6 \%$ in 2011 (European Commission 2012). While formal education is therefore undoubtedly on the rise, figures on educational mismatch are also high. A report by the European Union from 2012 shows that between 2001 and 2011 educational mismatch concerned 36\% of the workforce in the EU27 countries, albeit with large variations between countries with low incidence (such as Slovakia with only 16\%) and high incidence of over- or undereducated workers (such as Ireland with $51 \%$ ). The scope of these phenomena marks a stark contrast with the absence of empirical studies looking at how they affect the bottom line of firms facing a combination of a general increase in educational norms and a significant share of workers who do not fulfil them.

The remainder of the paper is organised as follows. A review of the literature is presented in Section 2. Sections 3 and 4 respectively describe our methodology and dataset. Econometric results are presented in Section 5. The final section discusses the results and concludes.

\section{Literature review}

\subsection{Educational mismatch and productivity-wage gaps}

Although labour economists have produced an abundant literature on the link between educational credentials and wages (Becker 1975, Card 1999), it becomes increasingly problematic that most empirical studies have relied on the assumption that these credentials accurately reflect labour productivity. Indeed, the recent literature on wage discrimination has applied methodological advances - notably an approach pioneered by Hellerstein et al. (1999) - to extensive matched employer-employee datasets that provide direct measures of labour productivity. This allowed to re-examine the nexus between worker characteristics, labour productivity, wages and profits (Cardoso et al., 2011; Damiani et al., 2016; Devicienti et al., 2015; Konings and Vanormelingen, 2015; Nielen and Schiersch, 2014; van Ours and Stoeldraijer, 2010, 2011). Instead of merely assuming that wage differentials between educational groups mirror differences in productivity, which has long been the modus 
operandi of empirical research within the Mincer framework (Pereira and Martins 2004, Lemieux 2006), current state-of-the-art consists in estimating how the observed productivity differences between educational groups compare with observed differences in labour costs. If the productivity effect of additional schooling is higher (lower) than the effect on labour costs, the combined result of these two effects increases (decreases) the firm's profits in the form of positive (negative) rents. Only in the case in which productivity effects are exactly offset by changes in labour cost the conventional human capital hypothesis remains warranted.

The direct measurement of productivity and wage effects can be applied to elucidate the impact of educational norms, but also to study the deviations from the normal level of education in a job which is at the heart of the rapidly expanding literature on educational mismatch (Baert et al., 2013; Baert and Verhaest, 2014; Mavromaras and McGuinness 2012; Verhaest and Omey 2009, 2012; Verhaest and Van der Velden, 2013; Sattinger and Hartog 2013).

In this paper, a "norm" refers to the level of education that prevails in a given job profile. In other words, the normal level of education reflects the typical staffing practices of firms in each type of job. It is likely that educational norms are mostly driven by the level of skills that are necessary to perform the tasks of the job adequately. This also explains why there is substantial variation in norms across different jobs, with some jobs being more demanding and non-routine than others. Over longer time horizons there may also be variations in educational norms within jobs. In addition, firms can raise the average education of their workforce without exceeding prevailing norms in each job, for instance when they change their job mix by replacing jobs with low norms with jobs for which the typical level of education is higher.

Employing workers with credentials below prevailing norms appears to hamper productivity, whereas the effect of overeducation is still unsettled (Quintini, 2011; Kampelmann and Rycx, 2012, Grunau 2016). Mahy et al. (2015) highlight the importance of working environments as moderating factors in the relationship between educational mismatch and productivity. Regarding direct measures of wage and labour cost effects, most existing studies are consistent in that they suggest that the wage returns to educational credentials beyond the level required by the prevailing norm in a given job are in general positive. Moreover, wages rise even more when the educational norm that corresponds to the firm's job mix increases. 
The literature also finds that wage returns to undereducation are negative but not always significant (Duncan and Hoffman, 1981; Rumberger, 1987; Sicherman, 1991; Battu et al., 1999; Galasi, 2008).

This paper overcomes the complete absence of studies that pull the productivity and labour cost effects together: we use linked employer-employee data to estimate how changes in educational norms and deviations from these norms affect productivity, labour cost and profits. Indeed, partial analyses of only wage effects or only productivity effects are all but irrelevant from the perspective of the firm. For instance, the profitability of the latter does not suffer from higher labour costs per se, but only when these higher costs are not at least offset by hikes in productivity. Rational profit-seeking firms change their labour force composition only if these changes generate positive productivity-wage gaps.

\subsection{Theoretical explanations for productivity-wage gaps}

Turning to the theoretical mechanisms that potentially drive the effects of educational mismatch on firm profits boils down to asking under which circumstances the educational composition of a firm's workforce has a different effect on labour costs than on productivity. Since the focus of this paper lies on the empirical estimation of productivity-wage gaps related to normal, under- and overeducation, we do not reiterate the numerous mechanisms that have been put forward in the large theoretical literature in this field. Following the literature overview in Kampelmann and Rycx (2011), these mechanisms can be divided into a) theories based on efficiency and individual rationality (e.g. when over- or undereducated workers differ from workers with normal education in terms of quasi-fixed costs or firmspecific skills, or when efficiency considerations lead firms to compress the wage structure of firms so as to avoid shirking or demotivation - see e.g. McGuinness (2006) and Cardoso (2010)); and b) institutionalist theories (e.g. when monopsony power, market regulations, wage norms or collective bargaining is associated with positive or negative rents that differ for over-, under- and normally educated workers - see e.g. Quintini (2011) and Konings and Vanormelingen (2015)).

Since empirical productivity-wage gaps are likely to confound several of these mechanisms, it is complicated to formulate a priori hypotheses regarding our estimates. However, given that we are looking at the Belgian private sector economy, a probable outcome is that the strong 
role of occupational categories in wage determination in this country leads to firms receiving positive rents when they employ overeducated workers, whereas undereducated workers are likely to be associated with negative rents. Put differently, overeducation (undereducation) is expected to have a stronger positive (negative) effect on productivity than on wages. This being said, this prediction might be attenuated by the fact that collective bargaining agreements also typically foresee binding rules for wage differentiation according to educational credentials within occupational categories, meaning that some overeducated workers will automatically receive higher wages compared to the average colleague in the same job. In this case, a share of any positive rents is converted into higher wages, whereas negative rents are absorbed by lower wages because the wages of undereducated workers will generally lie below the average wage in their occupational category.

\subsection{Impact of the firm's environment}

There are compelling theoretical arguments according to which the extent of productivitywage gaps associated with educational mismatch will differ across sectors and work environments. One obvious reason for this is the segmentation of labour markets. Firms requiring a workforce with higher skills typically face supply constraints that are absent in low-skilled environments. This should decrease rents and benefit wages, independently of whether the former arise for over-, under- or normally educated workers. On the other hand, in high-skilled sectors competences may be firm-specific so that some employers are in a position to extract economic rents from their monopsony power.

Prendergast (2002) suggests that economic uncertainty leads to a closer match between wages and productivity. In uncertain environments, the argument goes, more responsibilities are delegated to workers with higher education, which in turn could lead to higher wages for (over-) educated workers and a cap on firm rents. This theory is corroborated by Foss and Laursen (2005), who show that in high-skilled jobs increased productivity is associated with higher wages instead of extra profits. Barth et al. (2008) also suggest a close tie between productivity and wages for jobs that require high autonomy, which is another characteristic of uncertain or high-tech environments. This implies that overeducated workers, which Barth et al. find to be more productive in such contexts, reap the benefits of their productivity in form of higher wages. Conversely, according to the arguments presented by Milgrom (1988) and Milgrom and Roberts (1990), a rational firm in environments characterised by (i) jobs 
requiring relative high skills, (ii) sophisticated production technology (i.e. high-tech sectors) and (iii) high uncertainty will compress its wage structure in order to avoid opportunistic behaviour and rent-seeking activities. In this case, groups with higher productivity are paid below their marginal product, whereas the opposite is the case for low-productivity workers.

\section{Estimation framework}

\subsection{Baseline specification}

The literature offers three ways to measure the normal level of education for a job and the incidence of educational mismatch (see Hartog (2000) for a discussion). The first one, called the objective measure or job analysis approach is based on the evaluation by professional analysts of the level and type of education that is required for a specific job. The American Dictionary of Occupational Titles (DOT) is an example of such approach. The second approach, called subjective or self-assessment approach, requires the employee/employer to determine the type and level of formal education that is associated with the achievement of the tasks in a given job. This measurement thus rests on employee and/or employer surveys. The third approach, called empirical or realized matches approach, derives the normal level of education for a job from what workers in the corresponding job or occupation usually have attained. The educational norm is then generally computed on the basis of the mode of the education in a given occupation.

Each measure has its own advantages and weaknesses (for a detailed discussion see e.g. McGuinness (2006)). For instance, the job analysis approach is appealing because it is based on clear definitions and explicit measurement instructions. However, because of the cost and difficulty of this exercise, classifications based on job analysis are only published from time to time. Moreover, given that technological progress is likely to affect rapidly the content and complexity of jobs, classifications become fast outdated. Another point is that there is no such classification for Belgium and the use of a foreign one would probably create important measurement errors given that job classifications and requirements vary across countries. The second approach, based on workers' self-assessment, interestingly relies on local up-to-date information. However, it suffers from the fact that it is not based on rigorous instructions. In particular, respondents may overstate the requirements of their own job. It also typically leads to a downward biased proportion of under-educated workers. Finally, the realized matches 
approach has the advantage that it can be implemented easily and on a regular basis. Moreover, in contrast to the self-assessment approach, it enables to estimate more easily how much a worker is over- or undereducated. However, as Hartog (2000) argues, the realized matches method reflects the equilibrium between actual supply and demand and does not measure real requirements for a job as such, but rather the actual assignment practice as determined by hiring standards and labour market conditions.

Overall, it is impossible to say that one measure is strictly better than the others and in practice the choice of a measure is often dictated by data availability (Verhaest and Van der Velden (2013)). Given the feature of ours, we use realized matches in this paper. This method is based on the observed normal level of educational attainment of workers in each occupational category. We computed the educational norm for a given job by taking the mode of workers' years of education within detailed ISCO 3-digit occupations (113 categories) for each of the 12 years in our sample, yielding as much as 1,356 occupation-year norms ${ }^{3}$ and used this information to define our three main explanatory variables.

The first is the extent of normal education in firm $j$ at year $t$. This variable is obtained by summing up the years of normal education associated to the different jobs $i$ in firm $j$ at time $t$ $\left(N_{i, j, t}\right)$. For example, if a firm employs 5 workers, namely a managing director, an administration professional, a general office clerk, a shop salesperson and a cashier, than the extent of normal education in that firm will correspond to the sum of the normal years of education associated to these 5 different jobs. The normal years of education for a cashier (i.e. the mode of years of education in the ISCO category 523 across the entire private sector at time $t$ ) might be for instance equal to 9 (which corresponds to a lower secondary education degree) while those for an administration professional (ISCO category 242) may be equal to 16 (which corresponds a master's degree). For a given number of employees, firms can increase (decrease) the total amount of normal years of education by upgrading (downgrading) the firm's job mix towards jobs with higher (lower) educational norms. In our example, upgrading may notably result for the replacement of the general office clerk by a department manager (whose normal years of education is higher).

\footnotetext{
${ }^{3}$ The workers' educational attainment is available in 7 categories in our dataset. This information, reported by firms' human capital departments (on the basis of their registers), has been transformed in years of education. To this end, we applied the following rule: (i) primary education: 6 years of education; (ii) lower secondary education: 9 years of education; (iii-iv) general, technical and artistic upper secondary education: 12 years of education; (v) higher non-university education, short: 14 years of education; (vi) university and non-university education, long: 16 years of education; (vii) post-graduate education: 17 years of education.
} 
The second explanatory variable is the extent of overeducation. It is calculated by summing up the years of education in firm $j$ and year $t$ that exceed prevailing norms. Put differently, we make the sum over all workers $i$ employed in firm $j$ at time $t$ of $O_{i, j, t}$, with $O_{i, j, t}=$ Attained education $_{i, j, t}-N_{i, j, t}$ (where Attained education $_{i, j, t}$ is the number of years of schooling attained by worker $i$ and $N_{i, j, t}$ the normal years of education associated to workers' $i$ job). For example, a worker with 10 years of education working in a job whose norm equals 8 years of education will add 2 years of "overeducation". Firms who place workers in occupations whose educational norms they exceed will therefore increase the extent of overeducation in their workforce.

The third explanatory variable reflects undereducation. It sums up the schooling that falls short of educational norms, i.e. $U_{i, j, t}=N_{i, j, t}$ - Attained education $n_{i, j, t}$. For example, a worker with 10 years of education in a job with an educational norm of 12 years adds 2 years of "undereducation". The more workers of this type a firm employs, the higher will be the extend of undereducation in its workforce.

To render these sums comparable across firms, the years of normal, over and undereducation $\left(N_{i, j, t}, O_{i, j, t}, U_{i, j, t}\right)$ are divided by $m_{j, t}$, which is the number of workers employed in firm $j$ at year $t$.

To examine the impact of these explanatory variables on firm productivity, wages and the productivity-wage gap, we use three specifications aggregated at firm level. More precisely, we estimate the following equations:

$$
\begin{aligned}
\ln \left(\frac{V A_{j, t}}{m_{j, t}}\right)= & \beta_{0}+\beta_{1}\left(\ln \left[\frac{V A_{j, t-1}}{m_{j, t-1}}\right]\right)+\left[\left(\beta_{2} \sum_{i=1}^{m_{j, t}} \frac{O_{i, j, t}}{m_{j, t}}\right)+\left(\beta_{3} \sum_{i=1}^{m_{j, t}} \frac{N_{i, j, t}}{m_{j, t}}\right)+\left(\beta_{4} \sum_{i=1}^{m_{j, t}} \frac{U_{i, j, t}}{m_{j, t}}\right)\right] \\
& +X_{j, t} \beta_{5}+Z_{j, t} \beta_{6}+\gamma_{t}+v_{j, t} \\
\ln \left(\frac{w_{j, t}}{m_{j, t}}\right)= & \beta_{0}^{*}+\beta_{1}^{*}\left(\ln \left[\frac{w_{j, t-1}}{m_{j, t-1}}\right]\right)+\left[\left(\beta_{2}^{*} \sum_{i=1}^{m_{j, t}} \frac{O_{i, j, t}}{m_{j, t}}\right)+\left(\beta_{3}^{*} \sum_{i=1}^{m_{j, t}} \frac{N_{i, j, t}}{m_{j, t}}\right)+\left(\beta_{4}^{*} \sum_{i=1}^{m_{j, t}} \frac{U_{i, j, t}}{m_{j, t}}\right)\right] \\
& +X_{j, t} \beta_{5}^{*}+Z_{j, t} \beta_{6}^{*}+\gamma_{t}^{*}+v_{j, t}^{*}
\end{aligned}
$$




$$
\begin{aligned}
\ln \left(\frac{P_{j, t}}{m_{j, t}}\right)= & \beta_{0}^{* *}+\beta_{1}^{* *}\left(\ln \left[\frac{P_{j, t-1}}{m_{j, t-1}}\right]\right)+\left[\left(\beta_{2}^{* *} \sum_{i=1}^{m_{j, t}} \frac{O_{i, j, t}}{m_{j, t}}\right)+\left(\beta_{3}^{* *} \sum_{i=1}^{m_{j, t}} \frac{N_{i, j, t}}{m_{j, t}}\right)+\left(\beta_{4}^{* *} \sum_{i=1}^{m_{j, t}} \frac{U_{i, j, t}}{m_{j, t}}\right)\right] \\
& +X_{j, t} \beta_{5}^{* * *}+Z_{j, t} \beta_{6}^{* *}+\gamma_{t}^{* *}+v_{j, t}^{* *}
\end{aligned}
$$

where $V A_{j, t}, w_{j, t}$ and $P_{j, t}$, are the productivity, labour cost and productivity-wage gap (i.e. the profit) of firm $j$ at year $t$, respectively. The dependent variable in equation (1) is therefore the logarithm of the value added (at factor costs) per worker. The dependent variable in equation (2) is the logarithm of the labour cost per worker. It is obtained by dividing the firm's total wage bill (including fixed and variable pay components, in kind benefits, employer-funded extra-legal advantages (related e.g. to health, early retirement or pension), hiring and firing costs, and payroll taxes) by the total number of workers. The dependent variable in equation (3) is the logarithm of the difference between the value added and labour cost per worker (i.e. the $\log$ gross operating surplus per worker) ${ }^{4} . X_{j, t}$ is a vector including aggregated characteristics of workers in firm $j$ at year $t$ : the share of the workforce that has at least 10 years of tenure, the fractions of workers respectively younger than 30 and older than 49, and the shares of women, blue-collar and part-time workers. $Z_{j, t}$ is a vector containing firm $j$ characteristics at year $t$ : the sectorial affiliation ( 8 dummies), the age and size (number of workers) of the firm, the conditional dispersion in hourly wages, and the level of wage bargaining ( 1 dummy). $\gamma_{t}$ is a set of 11 year dummies and $v_{j, t}$ is the error term. ${ }^{5}$

This approach therefore examines the relationship between average years of over-, normal and undereducation within firms, on the one hand, and the productivity, labour cost and productivity-wage gap (i.e. the profit), one the other hand, while controlling for year dummies and a range of worker and firm characteristics. ${ }^{6}$ This three-equations approach, pioneered by Hellerstein et al. (1999) and refined by van Ours and Stoeldraijer (2011) among others, is now

\footnotetext{
${ }^{4}$ As a robustness test, following van Ours and Stoeldraijer (2011), we also estimated equation (3) using as dependant variable the difference between the logarithm of the value added per worker and the logarithm of the labour cost per worker (rather than using the logarithm of the difference between the two variables). Results, available upon request, confirm our conclusions.

${ }^{5}$ The control variables that have been included in our regressions are in line with extant literature (for a review of the set of covariates that should be included in this type of analysis see e.g. Göbel and Zwick, 2009). As highlighted by Mahlmberg et al. (2013: 10): 'by including a rather broad set of independent variables, we account for heterogeneity among firms, in order to mitigate the bias that could be caused by omitted variables'.

${ }^{6}$ Note that: $\frac{1}{m_{j, t}}\left(\sum_{i=1}^{m_{j, t}} O_{i, j, t}+\sum_{i=1}^{m_{j, t}} N_{i, j, t}-\sum_{i=1}^{m_{j, t}} U_{i, j, t}\right)=\frac{1}{m_{j, t}} \sum_{i=1}^{m_{j, t}}$ Attained $_{i, j, t}$, i.e., the sum of the average years of overand normal education minus the average years of undereducation in firm $j$ at time $t$ is equal to the average years of education attained by the workers employed in firm $j$ at time $t$.
} 
standard in the literature on the productivity and wage effects of labour heterogeneity, notably in terms of age, gender and origin (Cardoso et al., 2011; Damiani et al., 2016; Devicienti et al., 2015; Garnero et al., 2014; Hellerstein and Neumark, 2004; Konings and Vanormelingen, 2015). To our knowledge, it has never been used to examine the nexus between educational mismatch, productivity and wages.

The coefficients associated with normal, over- and undereducation can be interpreted as follows. A positive (negative) estimate for $\beta_{2}, \beta_{2}^{*}$ and $\beta_{2}^{* *}$, respectively, means that a firm that increases the education of its workforce beyond the prevailing educational norms in each job category will increase (decrease) its productivity (equation 1), wage cost (equation 2), or profit (equation 3). Conversely, a positive (negative) estimate for $\beta_{4}, \beta_{4}^{*}$ and $\beta_{4}^{* *}$, respectively, can be interpreted as suggesting positive (negative) productivity/wage/profit effects that arise if a firm hires more workers with education below prevailing educational norms in the jobs it employs.

The coefficients $\beta_{3}, \beta_{3}^{*}$ and $\beta_{3}^{* *}$ can reflect two alternative phenomena: they can capture the effect of a) an increase in the normal level of education for the different job categories in a firm or b) that the firm has changed its job mix towards jobs with higher educational norms. An example of the first case is when the normal educational attainment in a given job category increases, for instance because the technology involved to carry out the job has become more complex. The computerization of many secretarial tasks could have led to such an increase in prevailing educational norms in clerical jobs. In this case, firms can increase the amount of education of their workforce without necessarily changing the job mix in the firm. An example of the second case is when firms modify their job mix by replacing jobs with relatively low educational norms (such as unskilled manual jobs) with jobs that require more education (such as managerial or supervisory jobs). For instance, a firm that moves from a production technology based on unskilled manual labour to an automated process with skilled machine supervisors is likely to increase the level of education that corresponds to the norms in the jobs it employs even if the prevailing norms in each job category have not changed. In both cases, we interpret positive estimates of $\beta_{3}, \beta_{3}^{*}$ and $\beta_{3}^{* *}$ as suggesting a positive association between the level of normal education that corresponds to the firm's job mix and the firm's productivity/wages/profits. 
The inclusion of the lagged dependent variable among the regressors renders the model dynamic and aims to account for the persistency in firm-level profits, wage costs and productivity. ${ }^{7}$ It is also likely to improve the identification of the parameters of interest (even though the coefficient on the lagged dependent variable is not a central issue in the analysis). Indeed, as illustrated by Bond (2002), the use of a dynamic model is necessary to obtain consistent results when estimating a production function with serially correlated productivity shocks and explanatory variables that are correlated to these shocks. While serial correlation of productivity shocks may arise if the effects of demand shocks are only partially captured by the industry-specific control variables (Hempell, 2005), the responsiveness of input factors to productivity shocks may be explained by an endogeneity issue (see below).

\subsection{Firm environments}

In light of the literature review, we test whether the impact of educational mismatch differs according to the characteristic of the environment in which the firm evolves. To this end, we estimate equations (1) to (3) separately for different clusters of firms and compare the corresponding coefficients across clusters.

Firstly, the technological environment is investigated using a taxonomy developed by Eurostat (2012), the HT/KIS nomenclature. This nomenclature gives the Nace 2- or 3-digit code, according to which some firms can be classified as high-tech/knowledge and others as low-tech/knowledge and covers industrial and service-oriented firms. The group of hightech/knowledge intensive firms belongs to sectors that are high-medium tech/knowledge intensive (HT/KIS), while the group of low-tech firms belongs to sectors that are medium-low tech/less knowledge intensive (non-HT/KIS).

\footnotetext{
${ }^{7}$ From a theoretical perspective, competitive forces should eliminate abnormal profits (McMillan and Wohar, 2011). This said, a large literature, dating back to Shepherd (1975) and Mueller (1977) and taken further by Bou and Satorra (2007) and others, suggests that profit persistence is large and inconsistent with the competitive framework. More recent papers further show that firms with above (below) normal profits have high (low) barriers to entry and exit (McMillan and Wohar, 2011). In light of this so-called 'persistence of profits literature', there are strong arguments for modelling profits in a dynamic way, i.e. for including the lagged dependent variable among covariates in equation (3). The assumption of persistent productivity both at the industry and firm level also finds some support in the literature (see e.g. Bartelsman and Doms, 2000). Researchers 'documented, virtually without exception, enormous and persistent measured productivity differences across producers, even within narrowly defined industries' (Syverson, 2011: 326). Large parts of these productivity differences are still hard to explain. The persistence of wage costs is also highlighted in the literature (see e.g. Fuss and Wintr, 2009; Heckel et al., 2008). Wage stickiness is notably the outcome of labour market institutions, adjustment costs and efficiency wages' motives.
} 
Secondly, the economic uncertainty of the firm's environment is evaluated through an indicator proposed by Mahy et al. (2011). It uses the mean rate of bankruptcy at a NACE 3digit level that is also supplied by Statistics Belgium. The first group gathers firms that belong to sectors registering a higher mean rate of bankruptcy than the average of the whole sample, while the second gathers firms belonging to sectors registering lower bankruptcy levels.

\subsection{Estimation techniques}

Equations (1) to (3) have been estimated with three different methods: pooled ordinary least squares (OLS), a fixed-effects (FE) model and the generalized method of moments (GMM) estimator developed by Arellano and Bover (1995) and Blundell and Bond (1998). The OLS estimator with standard errors robust to heteroscedasticity and serial correlation is based on the cross-section variability between firms and the longitudinal variability within firms over time. However, this OLS estimator suffers from a potential heterogeneity bias because firm productivity can be related to firm-specific, time-invariant characteristics that are not measured in micro-level surveys (e.g., an advantageous location, firm-specific assets such as patent ownership, or other firm idiosyncrasies).

One way to remove unobserved firm characteristics that remain unchanged during the observation period is to estimate a FE model. However, neither pooled OLS nor the FE estimator address the potential endogeneity of our explanatory variables. ${ }^{8}$ Yet, there might be some cyclical 'crowding out', namely a process by which highly educated workers take jobs that could be occupied by less educated ones during recessions, because of excess labour supply (Dolado et al, 2000). This assumption suggests that mean years of overeducation within firms may increase as a result of a lower labour productivity (and vice versa). To control for this endogeneity issue, in addition to state dependence of firm productivity and the presence of firm fixed effects, we estimate equations (1) to (3) with the dynamic system GMM (GMM-SYS) estimator. ${ }^{9}$

\footnotetext{
${ }^{8}$ Expected biases associated with OLS and the relatively poor performance and shortcomings of the FE estimator in the context of firm-level productivity regressions are reviewed in Van Beveren (2012).

${ }^{9}$ It is standard in the literature to use dynamic panel data methods such as those proposed by Arellano and Bond (1991) to overcome key econometric issues, in particular lag-dependency, firm fixed effects and endogenity of input shares. Accordingly, many recent papers rely on dynamic GMM methods to estimate the impact of workforce and job characteristics (e.g. age, gender and employment contracts) on productivity and/or labour costs (see e.g. Göbel and Zwick, 2012, 2013; Ilmakunnas and Ilmakunnas, 2011; Mahlberg et al., 2013; Nielen and Schiersch, 2012, 2014; Vandenberghe, 2013).
} 
The GMM-SYS approach boils down to simultaneously estimating a system of two equations (respectively in level and in first differences) and relying on internal instruments to control for endogeneity. More precisely, education variables are instrumented by their lagged levels in the differenced equation and by their lagged differences in the level equation. ${ }^{10}$ The implicit assumption is that differences (levels) in (of) productivity in one period, although possibly correlated with contemporaneous differences (levels) in (of) education variables, are uncorrelated with lagged levels (differences) of the latter. Moreover, differences (levels) in (of) education variables are assumed to be reasonably correlated to their past levels (differences).

Interestingly, the inclusion of the lagged dependent variable in the OLS, fixed-effects and GMM-SYS specifications provides an ad hoc test for the appropriateness of the latter. As outlined by Roodman (2009), this test consists in checking whether or not the regression coefficient on the lagged dependent variable obtained with system GMM falls between the OLS and fixed effects estimates.

\section{Data and descriptive statistics}

We use a combination of two large datasets covering the years 1999-2010. The first is the "Structure of Earnings Survey" (SES) that is carried out by Statistics Belgium. It covers all firms operating in Belgium with more than 10 workers and activities within sections $\mathrm{B}$ to $\mathrm{N}$ of the NACE Rev. 2 nomenclature. This survey gathers information on firms' characteristics (e.g., sector, number of workers, level of collective wage bargaining) as well as information on workers' characteristics (e.g., age, education, tenure, gross earnings, paid hours, sex, occupation). However, the SES does not provide any financial information. It has thus been merged with a firm-level survey, namely the "Structure of Business Survey" (SBS), also carried out by Statistics Belgium. This survey provides financial information (e.g., firm-level value added and gross operating surplus per worker). The merger of the two datasets has been realized by Statistics Belgium using the firms' social security numbers. ${ }^{11}$

\footnotetext{
${ }^{10}$ Bond and Söderbom (2005) provide a review of the literature regarding the identification of production functions. The authors notably highlight that adjustment costs of labour and capital can justify the use of lagged values (of endogenous variables) as instruments.

${ }^{11}$ Note that the coverage of the SBS is not the same as that of the SES, as it does not cover the entire financial sector (NACE K).
} 
Information in the SES refers to the month of October of each year, while data in the SBS are measured over entire calendar years, i.e., from January to December. To avoid running a regression where information on the dependent variable (collected for the entire year) precedes the recording of the explanatory variables (collected in October), all explanatory variables in equation (1) have been lagged by one year. This way, information on education is recorded in October in year $t$ and used to explain firm-level productivity during the calendar year $t+1$. The imperfect synchronization of the SBS and SES data might introduce some fuzziness into our estimates since we cannot exclude the occurrence of external events influencing productivity in the intermediate period. This concern could only be completely eliminated if we had firm-level information on education for the entire calendar year. This being said, even if this information were available, there are also arguments for using asynchronised information on education variables: it is difficult to conceive how changes in educational composition could generate immediate effects, and potential productivity effects are thus more likely to occur after a certain adjustment period. The slightly asynchronised use of SBS and SES is therefore arguably the best option in light of data availability and productivity dynamics.

Our sample contains firms that are observed in at least two consecutive years and therefore overrepresents medium-sized and large firms. ${ }^{12}$ Next, we exclude workers and firms for which data are missing or inaccurate. ${ }^{13}$ In addition, in order to guarantee that the level of normal education is computed on the basis of a sufficient volume of data, we dropped

\footnotetext{
${ }^{12}$ The SES is a stratified sample. The stratification criteria refer respectively to the region (NUTS-groups), the principal economic activity (NACE-groups) and the size of the firm. The sample size in each stratum depends on the size of the firm. Sampling percentages of firms are respectively equal to 10,50 and 100 percent when the number of workers is below 50, between 50 and 99, and above 100. Within a firm, sampling percentages of employees also depend on size. Sampling percentages of employees reach respectively 100, 50, 25, 14.3 and 10 percent when the number of workers is below 20, between 20 and 49, between 50 and 99, between 100 and 199 , and between 200 and 299. Firms employing 300 workers or more have to report information for an absolute number of employees. This number ranges between 30 (for firms with 300 to 349 workers) and 200 (for firms with 12,000 workers or more). To guarantee that firms report information on a representative sample of their workers, they are asked to follow a specific procedure. First, they have to rank their employees in alphabetical order. Next, Statistics Belgium gives them a random letter (e.g., the letter O) from which they have to start when reporting information on their employees (following the alphabetical order of workers' names in their list). If they reach the letter $\mathrm{Z}$ and still have to provide information on some of their employees, they have to continue from the letter A in their list. Moreover, firms that employ different categories of workers, namely managers, blue- and/or white-collar workers, have to set up a separate alphabetical list for each of these categories and to report information on a number of workers in these different groups that is proportional to their share in total firm employment. For example, a firm with 300 employees (namely, 60 managers, 180 white-collar workers and 60 blue-collar workers) will have to report information on 30 workers (namely, 6 managers, 18 white-collar workers and 6 blue-collar workers). For more details, see Demunter (2000).

${ }^{13}$ For instance, we eliminate a (very small) number of firms for which the recorded value added was negative.
} 
occupations at ISCO 3-digit level with less than 10 observations. ${ }^{14}$ We also eliminated firms with less than 10 observations, because the use of average values at firm level requires a suitable number of observations. ${ }^{15}$ Finally, we dropped a very small number of firms with more than one NACE 3-digit code (i.e., firms with more than one activity) over the considered period in order to get only one NACE 3-digit code per firm at aggregate level. Our final sample covering the period 1999-2010 consists of an unbalanced panel of 12,290 firmyear-observations and is representative of all medium-sized and large firms in the Belgian private sector $^{16}$, with the exception of large parts of the financial sector (NACE K) and the electricity, gas and water supply industry (NACE D+E).

[Insert Table 1 about here]

Descriptive statistics of selected variables are presented in Table 1. They show that the annual firm-level value added per worker represents on average 91,876 EUR and that workers' mean annual labour cost is evaluated at 48,666 EUR. ${ }^{17}$ The yearly gross operating surplus (i.e., the firms' profits) represents on average 43,210 EUR. The prevailing norm regarding years of education equals on average 12.01, while the proportions of over- and undereducated workers are respectively around 20 and $28 \%$. The average years of over- and undereducation within firms are respectively equal to 0.53 and 0.94 . Moreover, we find that around $28 \%$ of employees within firms are women, $52 \%$ are blue-collars, $61 \%$ are prime-age workers (i.e., between 30 and 49 years old), 37\% have at least ten years of tenure, and 16\% are part-time workers (i.e., work less than 30 hours per week). Firms have an average of 250 employees and are essentially concentrated in the following sectors: manufacturing (53\%); wholesale and retail trade, repair of motor vehicles and motorcycles (15\%); real estate activities, professional

\footnotetext{
${ }^{14}$ We did some robustness tests by fixing the threshold at 50 observations. However, given that the number of data points per occupation at the ISCO 3-digit level is quite large, this alternative threshold has little effect on sample size and leaves results (available on request) unaffected.

${ }^{15}$ This restriction is unlikely to affect our results as it leads to a very small drop in sample size.

${ }^{16}$ Larger firms are likely to employ a lower share of overeducated workers because they generally have more sophisticated HRM procedures (notably in terms of recruitment) and a wider range of jobs (Dolton and Silles, 2001). Moreover, the required level of education is probably better defined in bigger firms. As a result, the fact that medium and large firms are over-represented in our sample may under-estimate the incidence of overeducation. Yet, caution is required. Indeed, empirical results provided by Karakaya et al. (2007) suggest that the impact of firm size on overeducation is very weak in the Belgian private sector. Using matched employeremployee data for 1995, the authors suggest that the likelihood for a worker to be overeducated decreases by only $0.1 \%$ ceteris paribus if firm size increases by 100 extra workers.

${ }^{17}$ All variables measured in monetary terms have been deflated to constant prices of 2004 by the consumer price index taken from Statistics Belgium.
} 
scientific and technical activities, administrative and support service activities (13\%); and construction $(9 \%)$.

\section{Estimation results}

\subsection{Baseline specification}

Given the aforementioned econometric issues associated with pooled OLS and the FE estimates, we focus on results of the GMM-SYS estimator. ${ }^{18,19}$ Table 2 reports the impact of education variables on per worker averages of added value, labour costs and profits (i.e. the gap between the former two). We first examine the consistency of our estimates by applying Hansen's (1982) and Arellano-Bond's (1991) tests; we do not reject the null hypothesis of valid instruments and of no second order autocorrelation.

[Insert Table 2 about here]

The results further indicate that current productivity is positively and significantly related to its value in the previous year. ${ }^{20}$ As regards educational mismatch variables, estimates show that the levels of normal and overeducation both exert a significant and positive impact on productivity, whereas the level of undereducation affect productivity negatively. More precisely, an increase of the prevailing norm in the firm by one year of schooling is associated with a $2.3 \%$ increase in the value added of the subsequent year. The same increase is

\footnotetext{
${ }^{18}$ OLS and FE estimates, not reported here for the sake of brevity, are available on request.

19 Detailed dynamic system GMM estimates, including control variables, are also available on request. Interestingly, regression coefficients associated to the covariates are in line with earlier findings. Industry dummies, for instance, are generally significant and they follow a similar pattern than that reported in the literature on inter-industry wage differentials (see e.g. du Caju et al., 2012). Among the highly productivity sectors, we notably find the electricity, gas and water supply industry (NACE D and E) and financial and insurance activities (NACE K). Not surprisingly, as shown in du Caju et al. (2011), these sectors are also found at the top of the conditional wage distribution. The coefficient on part-time is found to be significantly negative. This corroborates estimates of Devicienti et al. (2015) showing that firms employing more part-timers are ceteris paribus less productive. An insignificant coefficient for blue-collar workers is also reported in Kampelmann and Rycx (2012). The authors find that occupations play different roles for remuneration and productivity in the Belgian private sector. While their estimations indicate a significant upward-sloping occupational wage-profile, they cannot reject the hypothesis of a flat productivity-profile. Finally, the insignificant coefficient associated to the share of women is in line with Garnero et al. (2014). The latter show that women are associated to economic rents.

${ }^{20}$ This confirms (see footnote 7) that productivity but also wage costs and profitability (see columns 3 and 4 of Table 2) are highly persistent at the firm level. Moreover, GMM coefficients on lagged dependent variables fall systematically between the OLS and FE estimates (available on request). As highlighted by Roodman (2009), these results support the appropriateness of our dynamic GMM-SYS specification.
} 
estimated for each additional year of overeducation. Regarding undereducation, a $1.1 \%$ decrease in productivity is expected when average undereducation in the firm increases by one year.

Turning to the impact of educational mismatch on labour costs, our GMM-SYS estimates suggest that lagged labour costs positively and significantly influence their current value. Concerning educational mismatch variables, it appears that if a firm employs workers in jobs with higher normal education it can expect rising labour costs; an increase in the average level of normal education by one year is correlated with an increase of labour costs by $1 \%$ in the following year. Overeducation is also estimated to have a positive and significant impact on labour costs (an additional year of average overeducation is associated with a $2.3 \%$ increase in labour costs). Finally, our results suggest that undereducation has no significant influence on average labour costs.

It should be noted that our results for labour costs are not directly comparable to standard results in the educational mismatch literature. Indeed, most previous studies adopt the perspective of individual employees, use wages as dependent variable and find that the wage returns of overeducation are lower than the returns to the level of education that is required for a given job (McGuinness, 2006). By contrast, we look at the effects of educational mismatch from the perspective of the firm, which means that total labour costs is the more relevant outcome variable. As a consequence, we think that our finding that increases in overeducation has a larger effect on labour costs than upgrading to jobs with higher educational norms is not necessarily at odds with the literature. First, a standard t-test for equality of regression coefficients shows that the difference between the labour cost coefficients of normal and overeducation is actually not statistically significant. Second, there are theoretical and empirical arguments for why the impact of overeducation on labour costs could be stronger than on wages. For instance, overeducated workers exhibit higher turnover than their normally educated peers (McGuinness, 2006) - a difference that could generate extra (labour) adjustment costs borne by the employer. ${ }^{21}$ Third, even if wages represent the lion share of labour costs, the latter are nevertheless substantially higher, especially in a country like Belgium with very high (and progressive) payroll taxes, including employer social security contributions. It is therefore conceivable that overeducation has both a

\footnotetext{
${ }^{21}$ As highlighted in section 3.1, our measure of labour costs refers to the firm's total wage bill (including fixed and variable pay components, in kind benefits, employer-funded extra-legal advantages (related e.g. to health, early retirement or pension), hiring and firing costs and payroll taxes). Labour adjustment costs are thus taken into account.
} 
relatively lower effect than normal education on wages and a similar effect on labour costs. Fourth, unlike Mincer-type wage regressions, all of our equations include lagged dependent variables among the regressors. Yet, lagged labour costs will tend to capture the human capital profile of workers in the previous period, so that educational variables will capture only the impacts of changes in the shares that have occurred since the previous period, i.e. marginal rather than average effects - which is also why we focus our interpretation on the marginal impact of changes in the firm's educational mix rather than the total impact of educational norms and mismatches.

In order to investigate whether the impact of education on productivity differs from the one on labour costs, we re-estimate the model using the productivity-wage gap as dependant variable. The results, reported in the last column of Table 2, suggest that firm profits significantly increase when both the level of normal and overeducation increase by one year. ${ }^{22}$ By contrast, profits decrease when the firm's workforce accumulates more years of undereducation with respect to prevailing educational norms. More precisely, increasing the mean years of normal (over-) education by one year is expected to increase profits, the year after, by $6.0 \%(5.1 \%)^{23}$, whereas increasing the mean years of undereducation lowers profits by $2.5 \%$.

\subsection{Interactions with the firm's environment}

We now examine to what extent our benchmark results covering the entire private sector economy change when we account for the different environments in which firms evolve.

\subsubsection{Technology/knowledge intensity}

We first estimate whether the effects of educational mismatch on our three dependent variables depend on the technological/knowledge intensity of the firm's environment. For this purpose, we divide the dataset into two subsamples according to the HT/KIS nomenclature and run separate regressions on 3,888 firm-year observations of high-technology/knowledge firms and 8,402 firm-year observations of low-tech/knowledge firms.

\footnotetext{
${ }^{22}$ It should be recalled that the mean value of productivity is almost twice bigger than the mean value of labour costs within firms in our sample (see Table 1). Hence, although the estimated elasticity between productivity and overeducation (on the one hand) and labour costs and overeducation (on the other) is the same, it is not surprising to find that overeducation exerts a significant positive impact of firm profits.

${ }^{23} \mathrm{~A}$ standard $t$-test indicates that regression coefficients associated to normal and overeducation in the profit regression are not significantly different from each other.
} 
[Insert Table 3 about here]

The reliability of the GMM estimates is assessed through Arellano-Bond (1991) and Hansen (1982) tests. As shown in Table 3, we can neither reject the null hypothesis of valid instruments nor the null hypothesis of no autocorrelation for our estimates concerning productivity and labour costs; only for the profit regression and the subsample of low-tech firms there are signs of autocorrelation. This, however, does not appear to bias the estimates presented in the table because we obtain similar results with our second measure of productivity-wages gaps (see footnote 4).

According to the productivity coefficients presented in Table 3 (second and third columns), the effects of the educational variables are larger when the firm operates in an environment with greater knowledge intensity. Increasing the level of normal education by one year is expected to increase firm productivity by $2.5 \%$ in a low-tech environment, but by $3.4 \%$ in a high-tech environment. ${ }^{24} \mathrm{~A}$ one year increase in the level of overeducation is expected to increase firm productivity by $5.0 \%$ in a high-tech environment, which is 2 percentage points higher compared to a low-tech one. Increasing the level of undereducation by one year is expected to decrease firm productivity by $1.3 \%$ in a low-tech environment, but has no significant effect in high-tech firms.

Regarding labour costs, the estimates in the fourth and fifth columns of Table 3 show that the educational variables are only correlated with higher labour costs in high-tech environments. In this subsample, increasing the level of normal education by one year is expected to increase labour costs in the subsequent year by $2.5 \%$. A one-year increase in the mean years of overeducation is expected to increase labour costs by $3.0 \%$.

Results concerning the impact on profits are presented in the sixth and seventh columns of Table 3. The estimates suggest that gains (losses) in productivity are not entirely offset by higher (lower) labour costs, as we observe extra profits (losses) in subsamples. Extra profits related to the levels of normal and overeducation are relatively higher in high-tech firms:

\footnotetext{
${ }^{24}$ Standard $t$-tests for equality of coefficients (available on request) indicate that differences in regression coefficients (associated to a given educational variable) across economic environments are statistically significant. In contrast, as in our benchmark specification, $t$-tests show that regression coefficients associated to normal education and overeducation, for a given economic environment, are never statistically different from each other. These comments also apply to results discussed in section 5.2.2.
} 
increasing the educational norm by one year is associated with increases in profits by $6.6 \%$ and $7.5 \%$ in low and high tech environments, respectively; a one year increase in the mean years of overeducation is expected to increase profits by $6.7 \%$ and $11 \%$ for low-tech and high-tech firms. Finally, increasing the level of undereducation by one year is expected to decrease firm profits by $2.8 \%$ for low-tech firms. ${ }^{25}$

\subsubsection{Economic uncertainty}

We now present evidence on whether the educational composition of the firm affects productivity, labour costs and profits differently in more uncertain environments. The first regression is run on a subsample of 4,685 firm-year observations of firms in a more uncertain economic context (for definitions see Section 3.2); the second regression is based on the subsample of 7,605 firm-year observations of firms in relatively stable environments.

\section{[Insert Table 4 about here]}

With the exception of the profit equation in the subsample of firms facing high uncertainty, all regressions pass the Arellano-Bond and Hansen tests. ${ }^{26}$ The first two columns of Table 4 suggest that the impact of the educational composition of the workforce on productivity is bigger when the firm operates in a more uncertain economic context. More precisely, increasing the level of normal (over-) education by one year is expected to increase labour productivity by $2.4 \%(2.2 \%)$ in a more stable environment, whereas it is expected to increase productivity by $3.1 \%(4.0 \%)$ in a more uncertain sector of the economy. ${ }^{27}$ Concerning undereducation, a one-year increase is expected to decrease productivity by $0.9 \%$ in a context of low uncertainty, compared with a $1.2 \%$ decrease in a more uncertain environment.

\footnotetext{
${ }^{25}$ As stated above, results concerning the impact of educational mismatch on profits do not pass the ArrelanoBond test in the subsample of low-tech firm. To tackle this issue, we re-estimated equation (3) by computing the dependant variable as the difference between the logarithm of the value added per worker and the logarithm of the labour cost per worker instead as the logarithm of the difference between the value added per worker and the labour cost per worker. The results, available on request, pass the tests and confirm the estimates presented in Table 3, i.e. the coefficients also show an increase in profits for additional years of normal and overeducation and a decrease in profits for additional year of undereducation.

${ }^{26}$ The fact that we cannot reject autocorrelation with the Arellano-Bond test for the profit regression in more uncertain environments does not appear to bias our results, as our robustness test with an alternative specification of the productivity-wage gap pass the tests and leads to similar coefficients (see footnote 4).

27 Again, $t$-tests for equality of coefficients (available on request) indicate the differences in regression coefficients (associated to a given educational level) across economic environments are statistically significant (see footnote 25).
} 
Labour costs coefficients presented in the fourth and fifth column of Table 4 suggest stronger effects in a more uncertain environment. Increasing the level of normal education by one year is expected to raise labour costs by $1.2 \%$ and $2.1 \%$ under low and high uncertainty, respectively. Concerning overeducation, a one year increase in the mean years of overeducation is expected to increase labour cost by $4.1 \%$ in a more uncertain economic context whereas the effect is not significant in the other subsample. Finally, the extent of undereducation is not significant in both subsamples.

Results related to context-specific productivity-wages gap are reported in the sixth and seventh column of Table 4. They suggest that size of all effects is larger under higher uncertainty. A one-year increase in the mean years of normal education increases profit by $4.5 \%$ and $8.2 \%$ under low and high uncertainty, respectively. Increasing the level of overeducation by one year is expected to increase firm' profits in the two subsamples by $5.2 \%$ and $7.3 \%$. Undereducation is not significant in the low uncertainty sample but associated with a decrease in profit of $3.8 \%$ for each additional year of undereducation in a more uncertain environment.

\section{Discussion and conclusion}

Using a large linked employer-employee panel dataset covering the Belgian private sector over the period 1999-2010, this paper provides first evidence regarding the direct impact of educational mismatch on firm productivity, labour costs and profitability. It therefore fills a gap in the literature on educational norms and educational mismatch as existing studies have not been able to address frontally the question whether productivity effects associated with over- and undereducation are offset by corresponding changes in labour costs. Moreover, the paper is the first to assess how the impact of educational mismatch on direct measures of profitability differs according to the firm's economic environment.

Our findings - based on the GMM-SYS estimator and controlling for a large set of covariates, simultaneity issues, time-invariant unobserved workplace and firm characteristics and dynamics in the adjustment process of productivity, wages and profits - suggest that educational mismatch has a stronger impact on firm productivity than on labour costs. This gives rise to a profitability profile in the form of an inverted L: at the firm level, undereducation is associated with a negative impact on profits, whereas higher levels of 
normal and overeducation are correlated with positive economic rents of roughly the same magnitude (see Figure 1). This inverted L shape stems from the fact that the positive impact of normal and overeducation on productivity is only partly off-set by relatively higher labour costs. In other words, both upgrading the educational norms in a firm and hiring workers with credentials beyond prevailing norms are associated with positive rents. By contrast, the lower productivity of undereducated workers is not associated with significantly lower wages, so that the combined effect on profits is negative.

[Insert Figure 1 about here]

These findings are consistent with theoretical expectations in light of Belgium's relatively compressed wage structure, a result of labour institutions such as strong centralised collective bargaining. They suggest that wage compression limits wage decreases for undereducated workers more than they cap wage increases for overeducated workers - a result that could be due to binding wage floors like Belgium's national and sectoral minimum wages (Garnero, et al., 2014). The increased profitability associated with upgrading the firm's job mix and/or hiring more overeducated workers can also be the result of profit-maximising rent extraction by the employers. It should be noted that the policy implications of these alternative explanations are somewhat different: if rigidities in wage bargaining institutions drive our results, then labour market policies should be made more flexible to bring labour costs closer to productivity; by contrast, if the higher profitability is seen as unfair rent extraction on the expense of employees, this calls for stronger wage bargaining institutions so that highly educated workers can capture more of the economic rent that their employment appears to entail.

We further show that the profitability profile of educational mismatch varies with respect to the environment in which the firm operates. Whereas the subsample of low-tech firms displays a similar inverted L shape than the baseline regression, the profile is steeper in hightech firms: for them, hiring beyond educational norms is even more attractive as overeducated workers have such a high positive effect on productivity that overeducation easily offsets the associated hike in labour costs (see Figure 1). This is further evidence for wage compression, either due to the precited labour institutions or the efficiency arguments put forward by Milgrom (1988) and Milgrom and Roberts (1990). It is not in line with theories predicting a 
closer match between productivity and wages for more (over-) educated workers (Barth et al. 2008).

Comparing the profitability profiles of educational mismatch in firms facing low and high uncertainty confirms theoretical expectations: the profile of firms in relatively stable environments is more flat, meaning that the effects of under- and overeducation are slightly less consequential compared to the baseline profile. In particular, undereducation is not associated with negative rents, arguably because firms in stable environments are able to avoid unprofitable mismatches. In uncertain environments, the inversed L profile is stretched, with all effects being larger compared to the baseline regression. This suggests that uncertainty amplifies the effects of educational mismatch on profitability rather than changing their sign.

To conclude, the results presented in this paper underline important caveats of relying on the conventional human capital hypothesis assuming that wage differentiation in terms of educational credentials reflects productivity differences. First, increasing the amount of jobs with higher educational norms appears to be associated with productivity gains that surpass hikes in labour costs. In Belgium, the resulting rents are captured by firms in the form of higher profits. ${ }^{28}$ Second, while the human capital hypothesis correctly predicts higher productivity for overeducated workers, hiring beyond educational norms is also found to be profitable, especially in high-tech and more uncertain environments. This supports the idea, supported by Nelson and Phelps (1966) and Bulmahn and Kräkel (2002) among others, according to which higher, and by extension, more educated workers are more adaptable, more reactive, and thus more valuable in moving technological and more unstable contexts. Finally, our estimates show that firms employing under-educated workers are not only less productive but also less profitable. Given that undereducation is a sizable phenomenon in all advanced economies (Quintini, 2011), this is an alarming result. It notably calls for more initiatives to tackle bottleneck vacancies (i.e. labour shortages) and to ensure that workers' skills and knowledge remain up-to-date. ${ }^{29}$

\footnotetext{
${ }^{28}$ These results echo the estimates of Konings and Vanormelingen (2015). Using Belgian firm-level panel data, the latter show that on-the-job training (i.e. another component of workers' human capital) increases firms' profitability. Put differently, their results indicate that the productivity premium of a trained worker is substantially higher compared to the wage premium, an outcome that appears to be consistent with recent theories explaining work-related training by imperfect competition in the labour market.

${ }^{29}$ For examples of initiatives that could be implemented to reach these goals see e.g. European Commission (2014).
} 


\section{References}

Arellano, M., and Bond, S. (1991). Some tests of specification for panel data: Monte Carlo evidence and an application to employment equations. Review of Economic Studies, 58, 277-297.

Arellano, M., and Bover, O. (1995). Another look at the instrumental variable estimation of error-components models. Journal of Econometrics, 68, 29-51.

Baert, S., Cockx, B., Verhaest, D. (2013). Overeducation at the start of the career: Stepping stone or trap? Labour Economics, 25, 123-140.

Baert, S., and Verhaest, D. (2014). Unemployment or overeducation: Which is a worse signal to employers? IZA Discussion Papers, 8312.

Bartelsman, E., and Doms, M. (2000). Understanding productivity: Lessons from longitudinal microdata. Quarterly Journal of Economics, 122, 1721-1758.

Barth, E., Bratsberg, B., Haegeland, T. and Raaum, O. (2006). Who pays for performance? International Journal of Manpower, 29, 8-29.

Battu, H., Seaman, P., and Sloane, P. (1999). Overeducation, undereducation and the British labour market. Applied Economics, 31, 1437-1453.

Becker, G. (1975). Human Capital: A Theoretical and Empirical Analysis, with Special Reference to Education. University of Chicago Press, Chicago.

Blundell, R., and Bond, S. (1998). Initial conditions and moment restrictions in dynamic panel data models. Journal of Econometrics, 87, 115-143.

Bond, S. (2002). Dynamic panel data models: a guide to micro data methods and practice. Portuguese Economic Journal, 1, 141-162.

Bond, S., and Söderbom, M. (2005). Adjustment costs and the identification of Cobb Douglas production functions. IFS Working Paper, No. 05/04, London.

Bou, J., and Satorra, A. (2007). The persistence of abnormal returns at industry and firm levels: Evidence from Spain. Strategic Management Journal, 28, 707-722.

Bulmahn, G., and Kräkel, M. (2002). Overeducated workers as an insurance device. Labour, $16,383-402$.

Card, D. (1999). The causal effect of education on earnings, in Handbook of Labour Economics (Eds) O. Ashenfelter and D. Card, Vol. 3, North-Holland, Amsterdam.

Cardoso, A. (2010). Do firms compress the wage distribution?, in Wage Structures, Employment Adjustments and Globalisation: Evidence from Linked and Firm-level Panel Data (Eds) D. Marsden and F. Rycx, Palgrave Macmillan, pp. 202-218. 
Cardoso, A., Guimaraes, P., and Varejao, J. (2011). Are older workers worthy of their pay? An empirical investigation of age-productivity and age-wage nexuses. De Economist, 159, 95-111.

Cohn, E., and Khan, S. (1995). The wage effects of overschooling revisited. Labour Economics, 2, 67-76.

Damiani, M., Pompei, F. and Ricci, A. (2016). Performance related pay, productivity and wages in Italy: a quantile regression approach. International Journal of Manpower, 37, 232-256.

Demunter, C. (2000). Structure and distribution of earnings survey. DGSIE Working Paper. Brussels: Belgium.

Devicienti, F., Grinza, E. and Vannoni, D. (2015). The impact of part-time work on firm total factor productivity: evidence from Italy. IZA Discussion Paper, No. 9463, Bonn.

Dolado, J.J., Felgueroso, F. and Jimeno J.F. (2000). Explaining youth labor market problems in Spain: Crowding-out, institutions, or technology shifts? European Economic Review, 44, 943-956.

Dolton, P. and Silles, M. (2008). The effects of over-education on earnings in the graduate labour market. Economics of Education Review, 27, 125-139

du Caju, P., Rycx, F., and Tojerow, I.. 2011. Inter-industry wage differentials: How much does rent-sharing matter? Manchester School, 79, 691-717.

du Caju, P., Rycx, F., and Tojerow, I. 2012. Wage structure effects of international trade in a small open economy: the case of Belgium. Review of World Economics, 148, 297-331.

Duncan, G., and Hoffman, S. (1981). The incidence and wage effects of overeducation. Economics of Education Review, 1, 75-86.

European Commission (2012). Education and Training - Monitor 2012. Luxembourg: Publications Office of the European Union.

European Commission (2014). Mapping and Analyzing Bootleneck Vacancies in EU Labour Markets - Overview Report. Luxembourg: Publications Office of the European Union.

European Union (2009). Council Conclusions of 12 May 2009 on a strategic framework for European cooperation in education and training. Luxembourg: Official Journal C119 of 28.5.2009.

European Union (2012). Employment and Social Developments in Europe 2012. Luxembourg: Publications Office of the European Union.

Eurostat (2012). High-tech Statistics - Statistics Explained. Luxembourg: Eurostat. 
Foss, N.J., and Laursen, K. (2005). Performance pay, delegation and multitasking under uncertainty and innovativeness: An empirical investigation. Journal of Economic Behavior \& Organization, 58, 246-276.

Freeman, R. (1976). The Overeducated American. New York: Academic Press.

Fuss, C., and Wintr, L. (2009). Rigid labour compensation and flexible employment? Firmlevel evidence with regard to productivity for Belgium. ECB Working Paper, No. 1021, Frankfurt.

Galasi, P. (2008). The effect of educational mismatch on wages for 25 countries. Budapest Working Papers on the Labour Market, No. 8, Budapest.

Garnero, A., Kampelmann, S., Rycx, F. (2014). Part-time work, wages and productivity: evidence from Belgian matched panel data. Industrial and Labor Relations Review, 67, 926-954.

Göbel, C., and Zwick, T. (2009). Age and productivity: Evidence from linked employer employee data. ZEW Discussion Paper, No. 09-020, Mannheim.

Göbel, C., and Zwick, T. (2012). Age and productivity: Sector differences. De Economist, $160,35-57$.

Göbel, C. and Zwick, T. (2013). Are personnel measures effective in increasing productivity of old workers? Labour Economics, 22, 80-93.

Groot, W., and Maassen van den Brink, H. (2000). Overeducation in the labor market: a meta-analysis. Economics of Education Review, 19, 149-158.

Grunau, P. (2016). The impact of overeducated and undereducated workers on firm-level productivity: First evidence for Germany, International Journal of Manpower, 37: 258283.

Hansen, L. (1982). Large sample properties of generalized method of moments estimators. Econometrica, 50, 1029-1054.

Hartog, J. (2000). Over-education and earnings: Where are we, where should we go? Economics of Education Review, 19, 131-147.

Heckel, T., Le Bihan, H., and Montornès, J. (2008). Sticky wages: Evidence from quarterly microeconomic data. ECB Working Paper, No. 893, Frankfurt.

Hellerstein, J. and Neumark, D. (2004). Production function and wage equation estimation with heterogeneous labor: Evidence from a new matched employer-employee data set, NBER Working Paper, No. 10365, Cambridge (Ma.). 
Hellerstein J., Neumark D. and Troske K. (1999). Wages, productivity and worker characteristics: evidence from plant-level production functions and wage equations. Journal of Labor Economics, 17, 409-446.

Hempell, T. (2005). What's spurious? What's real? Measuring the productivity impacts of ICT at the firm level. Empirical Economics, 30, 427-464.

Ilmakunnas, P. and Ilmakunnas, S. (2011). Diversity at the workplace: whom does it benefit? De Economist, 159, 223-255.

Kampelmann, S., and Rycx, F. (2011). Are occupations paid what they are worth? An econometric study of occupational wage inequality and productivity. De Economist, 160, 257-287.

Kampelmann, S., and Rycx, F. (2012). The impact of educational mismatch on firm productivity: Evidence from linked panel data. Economics of Education Review, 31, 918931.

Karakaya, G., Plasman, R. and Rycx, F. 2007. Overeducation on the Belgian labour market: evaluation and analysis of the explanatory factors through two types of approaches. Compare, 37, 513-532.

Konings, J. and Vanormelingen, S. (2015). The impact of training on productivity and wages: Firm level evidence. Review of Economics and Statistics, 97, 485-497.

Lemieux, T. (2006) The 'Mincer equation' Thirty Years after Schooling, Experience, and Earnings, in Jacob Mincer: A Pioneer of Modern Labor Economics, S. Grossbard, ed., Springer: New York.

Mahlberg, B., Freund, I., Cuaresma J. and Prskawets, A. (2013). Ageing productivity and wages in Austria. Labour Economics, 22, 5-15.

Mahy, B., Rycx, F., and Volral, M. (2011). Wage dispersion and firm productivity in different working environments. British Journal of Industrial Relations, 49, 460-485.

Mahy, B., Rycx, F., and Vermeylen, G. (2015). Educational Mismatch and Firm Productivity: Do Skills, Technology and Uncertainty Matter? De Economist, 163, 233-262.

Mavromaras, K., and McGuinness, S. (2012). Overskilling dynamics and education pathways. Economics of Education Review, 31, 619-628.

McGuinness, S. (2006). Overeducation in the labour market. Journal of Economic Surveys, $20,387-418$.

McGuinness, S., and Sloane, P. (2011). Labour market mismatch among UK graduates: An analysis using REFLEX data. Economics of Education Review, 30, 130-145. 
McMillan, D., and Wohar, M. (2011). Profit-persistence revisited: The case of the UK. Manchester School, 79, 510-527.

Milgrom, P.R. (1988). Employment Contracts, Influence Activities, and Efficient Organization Design. Journal of Political Economy, 96, 42-60.

Milgrom, P.R., and Roberts, J. (1990). The efficiency of equity in organizational decision processes. American Economic Review Papers and Proceedings, 80, 154-159.

Mueller, D. (1977). The persistence of profits above the norm, Economica, 44, 369-380.

Nelson, R., and Phelps, E. (1966); Investment in humans, technological diffusion and economic growth. American Economic Review, 56, 69-75.

Nielen, S. and Schiersch, A. (2012). Productivity in German manufacturing firms: Does fixedterm employment matter? Schumpeter Discussion Paper, No. 4, Schumpeter School of Business and Economics, University of Wuppertal, Germany.

Nielen, S. and Schiersch, A. (2014). Temporary agency work and firm competitiveness: Evidence from German manufacturing firms. Industrial Relations, 53, 365-393.

Pereira, P. T., and Martins, P. S. (2004). Returns to education and wage equations. Applied Economics, 36, 525-531.

Prendergast, C. (2002). The Tenuous trade-off between risk and incentives. Journal of Political Economy, 110, 1071-1102.

Quintini, G. (2011). Over-qualified or under-skilled: A review of existing literature. OECD Social, Employment and Migration Working Papers, No. 121, OECD Publishing.

Roodman, D. (2009). How to do xtabond2: An introduction to difference and system GMM in Stata. Stata Journal, 9, 86-136.

Rumberger, R. (1987). The impact of surplus schooling on productivity and earnings. Journal of Human Resources, 22, 24-50.

Sanchez-Sanchez, N., and McGuinness, S. 2015. Decomposing the impacts of overeducation and overskilling on earnings: An analysis using Reflex data. Education Economics, 24, 419-432.

Sattinger, M., and Hartog, J. (2013). Nash bargaining and the wage consequences of educational mismatches. Labour Economics, 23, 50-56.

Shepherd, W. (1975). The treatment of market power. New York: Columbia University Press.

Sicherman, N. (1991). Overeducation in the labor market. Journal of Labor Economics, 9, $101-122$

Syverson, C. (2011). What determines productivity? Journal of Economic Literature, 49, 326365. 
Van Beveren, I. (2012). Total factor productivity estimation: A practical review. Journal of Economic Surveys, 26, 98-128.

van Ours, J.C., and Stoeldraijer, L. (2010). Age, wage and productivity. CESifo Working Paper, No. 2965. Munich.

van Ours, J.C., and Stoeldraijer, L. (2011). Age, wage and productivity in Dutch manufacturing. De Economist, 159, 113-137.

Vandenberghe, V. (2013). Are firms willing to employ a greying and feminizing workforce?. Labour Economics, 22, 30-46.

Verhaest, D., and Omey, E. (2009). Objective over-education and worker well-being: A shadow price approach. Journal of Economic Psychology, 30, 469-481.

Verhaest, D., and Omey, E. (2012). Overeducation, undereducation and earnings: further evidence on the role of ability and measurement error bias. Journal of Labor Research, 33, 76-90.

Verhaest, D. and Van der Velden, R. (2013). Cross-country differences in graduate overeducation. European Sociological Review, 29: 642-653. 
Table 1. Descriptive Statistics of Selected Variables, 1999-2010

\begin{tabular}{|c|c|c|}
\hline Variables & Mean & Std. Dev. \\
\hline Annual value added per worker ${ }^{\mathrm{a}}(€)$ & 91,876 & 612,545 \\
\hline Annual labour cost per worker ${ }^{\mathrm{a}}(€)$ & 48,666 & 24,163 \\
\hline Annual profit per worker ${ }^{\mathrm{a}}(€)$ & 43,210 & 610,313 \\
\hline Normal education (years) & 12.01 & 1.36 \\
\hline \multicolumn{3}{|l|}{ Overeducation } \\
\hline Percentage of workers & 20.35 & 22.08 \\
\hline Years & 0.53 & 0.62 \\
\hline \multicolumn{3}{|l|}{ Undereducation } \\
\hline Percentage of workers & 27.72 & 26.40 \\
\hline Years & 0.94 & 1.03 \\
\hline Workers with 10 years or more of tenure $(\%)$ & 37.44 & 23.75 \\
\hline Women $(\%)$ & 28.33 & 24.64 \\
\hline Blue-collar workers ${ }^{\mathrm{b}}(\%)$ & 52.39 & 35.22 \\
\hline Share of workers $<30$ years & 21.78 & 14.73 \\
\hline Share of workers between 30 and 49 years & 60.89 & 13.79 \\
\hline Share of workers $>49$ years & 17.33 & 12.51 \\
\hline Part-time $(\%)$ & 16.40 & 17.55 \\
\hline Firm size (number of workers) & 250.19 & 448.32 \\
\hline Firm-level collective agreement (\%) & 28.69 & 45.08 \\
\hline \multicolumn{3}{|l|}{ Sector $(\%)$} \\
\hline Mining and quarrying (B) & 0.68 & \\
\hline Manufacturing $(\mathrm{C})$ & 52.66 & \\
\hline \multicolumn{3}{|l|}{$\begin{array}{l}\text { Electricity, gas, steam and air conditioning } \\
\text { supply; Water supply, sewerage, waste } \\
\text { management and remediation }\end{array}$} \\
\hline activities (D+E) & 0.63 & \\
\hline Construction $(\mathrm{F})$ & 8.85 & \\
\hline $\begin{array}{l}\text { Wholesale and retail trade, } \\
\text { repair of motor vehicles and } \\
\text { motorcycles }(\mathrm{G})\end{array}$ & 15.28 & \\
\hline $\begin{array}{l}\text { Accommodation and food services } \\
\text { activities (I) }\end{array}$ & 1.81 & \\
\hline $\begin{array}{l}\text { Transport and storage ; Information and } \\
\text { communication }(\mathrm{H}+\mathrm{J})\end{array}$ & 5.88 & \\
\hline Financial and insurance activities $(\mathrm{K})$ & 1.59 & \\
\hline $\begin{array}{l}\text { Real estate activities ; Professional, } \\
\text { scientific and technical activities; } \\
\text { Administrative and support service } \\
\text { activities }(\mathrm{L}+\mathrm{M}+\mathrm{N})\end{array}$ & 12.60 & \\
\hline Number of firm-year observations & & 12,290 \\
\hline
\end{tabular}

Data source:SES-SBS 1999-2010.

Notes: ${ }^{\mathrm{a}}$ At 2004 constant prices. ${ }^{\mathrm{b}}$ The distinction between blue- and white-collar workers is based on the International Standard Classification of Occupations (ISCO-08). Workers belonging to groups 1-5 are considered to be white-collar workers (1: Managers; 2: Professionals; 3: Technicians and associate professionals; 4: Clerical support workers; 5: Services and sales workers), and those from groups 7-9 are considered to be blue-collar workers (7: Craft and related trades workers; 8: Plant and machine operators and assemblers; 9: Elementary occupations). 
Table 2 - Educational Mismatch and Productivity, Labour Costs and Gap (GMM estimates, 1999-2010)

\begin{tabular}{|c|c|c|c|}
\hline \multirow[t]{2}{*}{ Dependent variable } & \multicolumn{3}{|c|}{ GMM-SYS } \\
\hline & $\begin{array}{l}\text { Value added per } \\
{\text { worker }(\ln )^{\mathrm{d}}}\end{array}$ & $\begin{array}{c}\text { Labour cost } \\
\text { per worker }(\ln )^{\mathrm{e}}\end{array}$ & $\begin{array}{c}\text { Profit per } \\
\text { worker }(\ln )^{\mathrm{d}} \\
\end{array}$ \\
\hline Value added per worker (one year lagged, in ln) & $\begin{array}{c}0.623 * * * \\
(0.043)\end{array}$ & & \\
\hline Labour cost per worker (one year lagged, in ln) & & $\begin{array}{c}0.706 * * * \\
(0.059)\end{array}$ & \\
\hline Profit per worker (one year lagged, in ln) & & & $\begin{array}{c}0.413 * * * \\
(0.029)\end{array}$ \\
\hline Normal education (one year lagged, in years) & $\begin{array}{c}0.023 * * * \\
(0.005)\end{array}$ & $\begin{array}{l}0.010^{*} \\
(0.006)\end{array}$ & $\begin{array}{c}0.060 * * * \\
(0.017)\end{array}$ \\
\hline Overeducation (one year lagged, in years) & $\begin{array}{c}0.023 * * * \\
(0.007)\end{array}$ & $\begin{array}{l}0.023 * \\
(0.013)\end{array}$ & $\begin{array}{c}0.051 * * \\
(0.026)\end{array}$ \\
\hline Undereducation (one year lagged, in years) & $\begin{array}{c}-0.011 * * \\
(0.004)\end{array}$ & $\begin{array}{l}-0.006 \\
(0.007)\end{array}$ & $\begin{array}{l}-0.025^{*} \\
(0.014)\end{array}$ \\
\hline Worker characteristics ${ }^{\mathrm{a}}$ & YES & YES & YES \\
\hline Firm characteristics ${ }^{\mathrm{b}}$ & YES & YES & YES \\
\hline Year dummies (11) & YES & YES & YES \\
\hline Sig. model (p-value) & 0.000 & 0.000 & 0.000 \\
\hline Hansen statistic & 483.7 & 538.81 & 500.72 \\
\hline$p$-value & 0.41 & 0.20 & 0.22 \\
\hline Arellano-Bond statistic (AR2) ${ }^{\mathrm{c}}$ & 1.47 & 0.81 & 1.39 \\
\hline$p$-value & 0.14 & 0.42 & 0.17 \\
\hline Number of firm-year observations & 12,290 & 12,290 & 12,290 \\
\hline
\end{tabular}

Note: Robust standard errors are reported between brackets.

$(* * *, * *, *)$ : Significant at respectively $1 \%, 5 \%$ and $10 \%$ levels. ${ }^{\text {a }}$ Shares of the workforce that: (i) has at least 10 years of tenure, and (ii) is younger than 30 and older than 49 years, respectively. The shares of women, blue-collar and part-time workers as well as the conditional dispersion in hourly wages are also included. ${ }^{\mathrm{b}}$ Sectorial affiliation (8 dummies), number of workers, age of the firm, and level of wage bargaining (1 dummy). ${ }^{\mathrm{c}}$ AR2 displays the test for second-order autocorrelation in the first-differenced errors. ${ }^{\mathrm{d}}$ First and second lags of explanatory variables are used as instruments in the GMM specification, excluding time dummies. ${ }^{\mathrm{e}}$ Second and third lags of explanatory variables are used as instruments in the GMM specification, excluding time dummies. 
Dependent variable

Value added per worker

(one year lagged, in ln)

Labour cost per worker (one year

lagged, in $\ln$ )

Profit per worker (one year lagged,

in $\ln$ )

Normal education

(one year lagged, in years)

Overeducation

(one year lagged, in years)

Undereducation

(one year lagged, in years)

Worker Characteristics ${ }^{\mathrm{a}}$

Firm Characteristics ${ }^{\mathrm{b}}$

Year dummies (11)

Sig. model (p-value)

Hansen statistic

$p$-value

Arellano-Bond statistic (AR2)

$p$-value

\begin{tabular}{|c|c|}
\hline \multicolumn{2}{|c|}{ Value added per worker $(\ln )$} \\
\hline $\begin{array}{c}\text { Low- } \\
\text { Tech/Knowledge } \\
\text { Intensity }^{\mathrm{d}}\end{array}$ & $\begin{array}{c}\text { High- } \\
\text { Tech/Knowledge } \\
\text { Intensity }\end{array}$ \\
\hline $\begin{array}{c}0.535 * * * \\
(0.074)\end{array}$ & $\begin{array}{c}0.758 * * * \\
(0.037)\end{array}$ \\
\hline
\end{tabular}

(0.074)

(0.037)

\begin{tabular}{c} 
Labour cost \\
\hline Low- \\
Tech/Knowledge \\
Intensity $^{\mathrm{f}}$ \\
\hline \hline
\end{tabular}

\section{$0.611 * * *$}

$\begin{array}{cc}0.025 * * * & 0.034 * * \\ (0.007) & (0.014) \\ 0.030 * * * & 0.050^{*} \\ (0.008) & (0.028) \\ -0.013 * * * & 0.004 \\ (0.005) & (0.015)\end{array}$

YES

YES

YES

YES

YES

0.000

596.0

0.49

1.63

0.103

8,402

GMM-SYS

Number of firm-year observations

(0.075)

$\begin{gathered}\text { High-Tech/Know } \\ \text { Intensity }\end{gathered}$

$0.756^{* * *}$
$(0.054)$

$0.025^{* * *}$
$(0.009)$
$0.030 *$
$(0.016)$
-0.019
$(0.012)$

$\begin{array}{cc}0.006 & 0.025 * * * \\ (0.007) & (0.009) \\ 0.018 & 0.030 * \\ (0.011) & (0.016) \\ -0.003 & -0.019 \\ (0.007) & (0.012)\end{array}$

YES

YES

YES

0.000

453.5

0.32

0.48

0.63

\begin{tabular}{cc}
\hline \multicolumn{2}{c}{ Profit per worker (ln) } \\
\hline \hline Low- & High- \\
Tech/Knowledge & Tech/Knowledge \\
Intensity $^{\mathrm{g}}$ & Intensity $^{\mathrm{f}}$ \\
\hline \hline
\end{tabular}

$0.417 * * *$
$(0.035)$
$0.066 * * *$
$(0.019)$
$0.067 * *$
$(0.030)$
$-0.028 *$
$(0.016)$

$0.599 * * *$

(0.039)

$0.075^{* * * *}$

(0.025)

$0.110 * * *$

(0.042)

$-0.015$

(0.030)

YES

YES

0.000

626.7

0.11

0.33

0.74

3,887

3,888

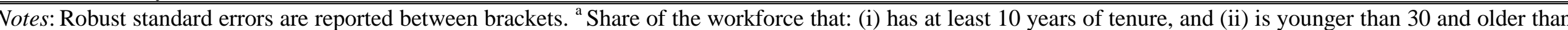

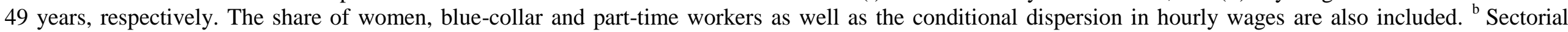

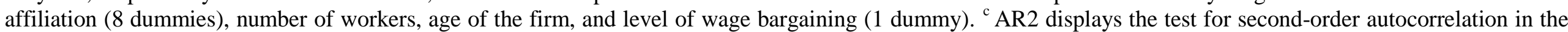

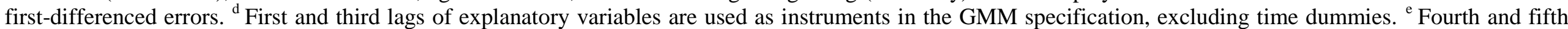

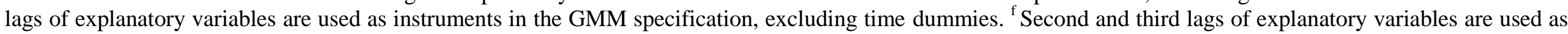

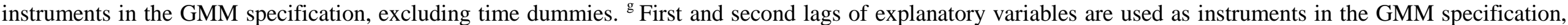
excluding time dummies. $* * *, * *, *$ significant at the 1,5 and $10 \%$ level, respectively. 
Table 4. Educational Mismatch and Productivity According to Economic Environment Uncertainty (GMM estimates, 1999-2010)

\section{GMM-SYS}

Dependent variable

Value added per worker

(one year lagged, in ln)

Labour cost per worker (one year

lagged, in $\ln$ )

Profit per worker (one year lagged,

in $\ln$ )

Normal education

(one year lagged, in years)

Overeducation

(one year lagged, in years)

Undereducation

(one year lagged, in years)

Worker Characteristics ${ }^{\mathrm{a}}$

Firm Characteristics ${ }^{\mathrm{b}}$

Year dummies (11)

Sig. model (p-value)

Hansen statistic

$$
p \text {-value }
$$

Arellano-Bond statistic (AR2)

$p$-value

Number of firm-year observations

\begin{tabular}{c}
\hline Less \\
Uncertain $^{\mathrm{d}}$ \\
\hline \hline \\
$0.690^{* * *}$ \\
$(0.082)$ \\
\\
\\
$0.012 *$ \\
$(0.007)$ \\
0.012 \\
$(0.013)$ \\
-0.010 \\
$(0.007)$
\end{tabular}

YES

YES

YES

0.000

498.1

0.41

0.66

0.51

0.12

4,685

(0.053)

YES

YES

YES

0.000

467.5

0.46

1.50

0.13

4,684
Labour cost per worker $(\ln )$

More
Uncertain $^{\mathrm{f}}$

$0.749 * * *$
$(0.053)$

$\begin{array}{ccc} & (0.033) & (0.048) \\ 0.021 * * * & 0.045^{* *} & 0.082^{* * *} \\ (0.007) & (0.019) & (0.023) \\ 0.041^{* * *} & 0.052^{*} & 0.073^{*} \\ (0.011) & (0.030) & (0.039) \\ -0.005 & -0.006 & -0.038^{*} \\ (0.010) & (0.016) & (0.023)\end{array}$

YES

YES

YES

YES

YES

YES

0.000

458.0

0.56

1.87

0.06

Notes: Robust standard errors are reported between brackets. ${ }^{a}$ Share of the workforce that: (i) has at least 10 years of tenure, and (ii) is younger than 30 and older than 49 years, respectively. The share of women, blue-collar and part-time workers as well as the conditional dispersion in hourly wages are also included. ${ }^{\mathrm{b}}$ Sectorial affiliation $(8$ dummies), number of workers, age of the firm, and level of wage bargaining (1 dummy). ${ }^{c}$ AR2 displays the test for second-order autocorrelation in the first-differenced errors. ${ }^{\mathrm{d}}$ First and third lags of explanatory variables are used as instruments in the GMM specification, excluding time dummies. ${ }^{\mathrm{e}}$ Fourth and fifth lags of explanatory variables are used as instruments in the GMM specification, excluding time dummies. ${ }^{\mathrm{f}}$ Second and third lags of explanatory variables are used as instruments in the GMM specification, excluding time dummies. ${ }^{\mathrm{g}}$ First and second lags of explanatory variables are used as instruments in the GMM specification, excluding time dummies. $* * *$, **, * significant at the 1,5 and $10 \%$ level, respectively. 
Figure 1: Comparison of profitability profiles of educational variables in Tables 2, 3 and 4

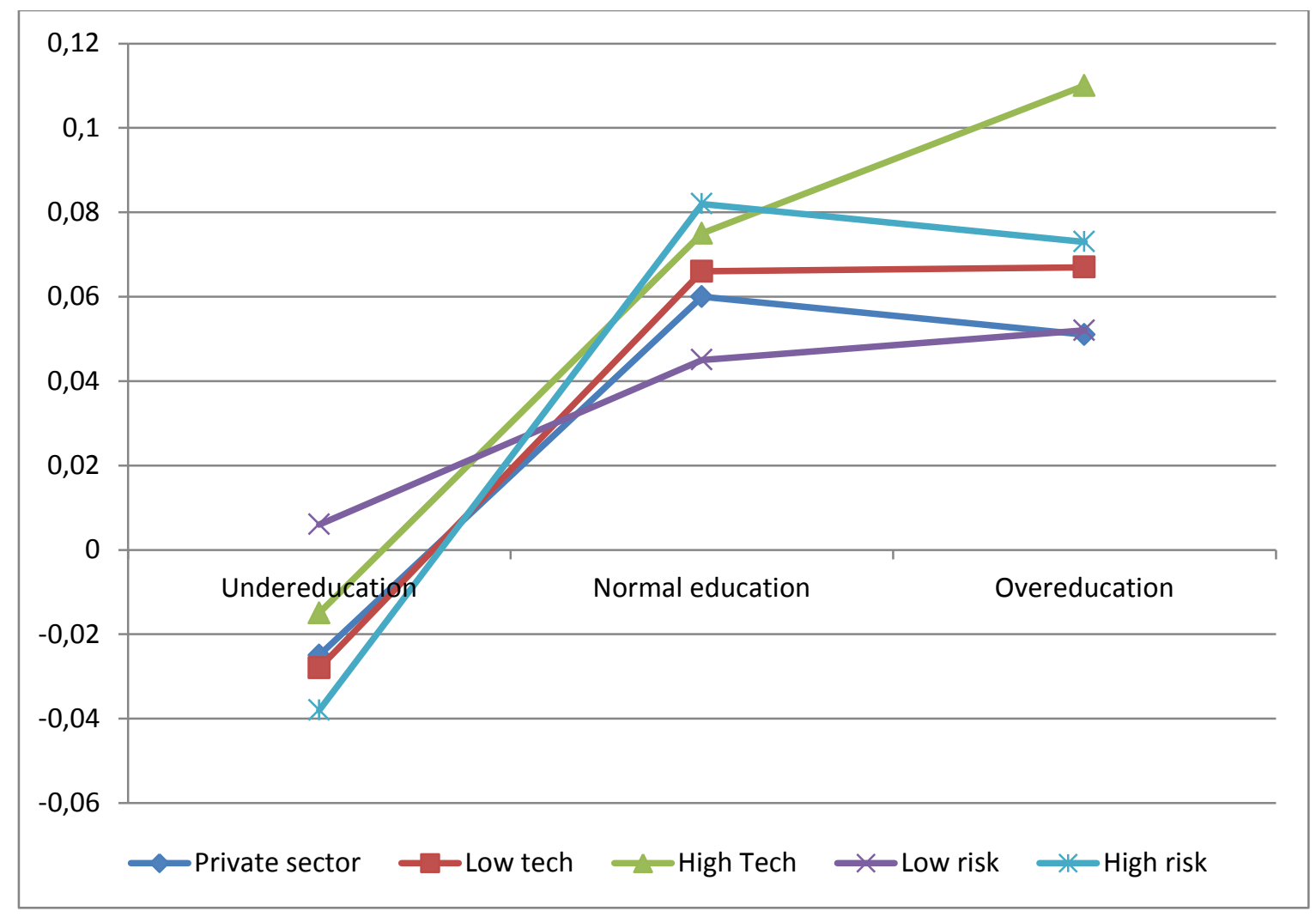

